\title{
3 comunitania)
}

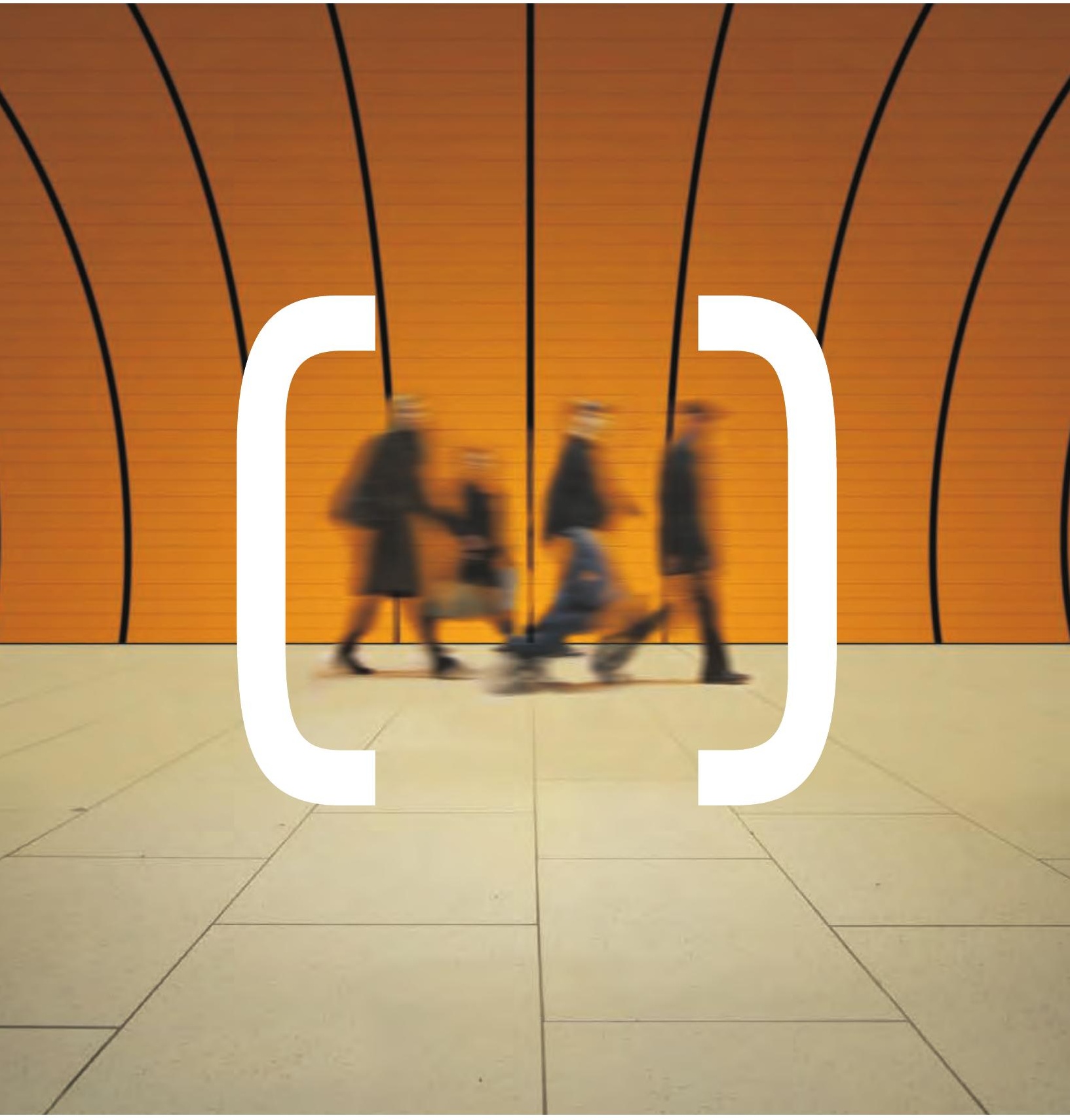

FÁTIMA YÁÑEZ | DAVID HERNÁNDEZ | JOSÉ ANTONIO RUIZ | LETICIA PORTO MIGUEL DEL FRESNO | SAGRARIO SEGADO | MARÍA DEL CARMEN DÍAZ 


\title{
The 2006 New York Convention and Obligations of Persons with Disabilities: Liability for Damages within the Scope of Civil Law and Common Law *
}

\section{Las obligaciones de las personas con discapacidad psíquica a la luz de la Convención de Naciones Unidas de 2006: especial consideración de la responsabilidad por daños}

\author{
Fátima Yáñez Vivero* \\ * Universidad Nacional de Educación a Distancia (UNED)
}

\begin{abstract}
:
The New York Convention on the Rights of Persons with Disabilities of 13 December 2006 repeatedly - even excessively - refers to the rights and freedoms of persons with disabilities. However, these rights must be combined with a corresponding assumption of obligations and responsibilities to ensure equal treatment for all parties. Specifically, the liability derived from damages caused to a third party by a person with a disability constitutes the object of this study. Some elements of this liability - especially regarding negligence - must be examined in relation to the disability itself to determine whether the elements are appropriate under the circumstances, such as damages arising from a psychological disability. The analysis of this issue shall be carried out from a comparative perspective, highlighting the agreements and disagreements between Civil Law and Common Law.
\end{abstract}

Keywords: mental disability, required standard of conduct, fault, liability, damages.

\section{Resumen:}

La Convención de Nueva York sobre los derechos de las personas con discapacidad, de 13 de diciembre de 2006, se refiere reiteradamente - incluso, en exceso - a los derechos y libertades de estas personas. Pero es obvio que el ejercicio de los derechos y libertades

* This work forms part of a line of investigation developed by the author and reflected in broader works such as the monograph entitled Culpa civil y daño extracontractual originado por persona incapaz. Un análisis en el marco del Derecho Europeo de Daños. Civil negligence and extra-contractual damages incurred by the disabled person. An analysis within the context of european tort law (Ed. Aranzadi, 2009). 
en igualdad de condiciones que el resto de sujetos no podrá llevarse a cabo, de modo pleno, si no lleva aparejada la correspondiente asunción de obligaciones y responsabilidades. En concreto, la responsabilidad derivada del daño causado a tercero por una persona con discapacidad constituye el objeto de este estudio. Para ello habrá que examinar algunos elementos de la responsabilidad - especialmente el de la culpa - y determinar su compatibilidad con determinadas circunstancias personales, como las derivadas de una discapacidad psíquica. El análisis de esta cuestión se llevará a cabo desde una perspectiva comparativa que pone de relieve los encuentros y desencuentros entre los ordenamientos pertenecientes al denominado Civil Law y los del Common Law.

Palabras clave: discapacidad psíquica, estándar de conducta exigible, culpa, responsabilidad civil, daños.

\section{Article info:}

Received: 16 / 06 / 2011 / Received in revised form: 19 / 11 / 2011

Accepted: 22 / 12 / 2011 / Published online: 30 / 01 / 2012

DOI: http://dx.doi.org/10.5944/comunitania.3.1

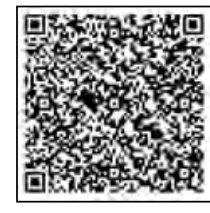

\section{The New York Convention of 13 December 2006 and the obligations of persons with disabilities}

When the rights of persons with disabilities are discussed in the contemporary framework, it is not very "popular" to refer to these subjects' obligations. However, if one intends to "promote and guarantee the full possession, in equal conditions, of all human rights and freedoms by all persons with disabilities" as established in the New York Convention on the Rights of Persons with Disabilities, then a corresponding assumption of obligations and responsibilities in the exercise of these rights and freedoms must also be adopted.

In spite of this, the Convention of 2006 omits any express reference to obligations or responsibilities of persons with disabilities. These can be deduced from Precept 8's reference to the commitment by Party States to adopt immediate, effective and relevant measures to "(...) b) Fight against stereotypes, prejudices and harmful practices with respect to persons with disabilities..." To exempt persons with disabilities from the corresponding civil liability for damages caused to third parties would constitute a stigma that would have to be eliminated from some civil codes, such as the Italian Civil Code of 1942.

Likewise, Article 12, under the title "Equal recognition as a person under the Law," establishes an unnecessary and self-evident point in its second section: "... The Party States shall recognize that persons with disabilities have legal capacity in conditions equal to others in all aspects of life." This implies a potential assumption that some persons could be deprived of legal capacity due to their disability. The same precept attempts to guarantee the exercise of this legal capacity (albeit in a generic manner), 
except within the scope of economic or asset ownership. In these instances, according to section five of Article 12, the intention is to "guarantee the right of persons with disabilities, in conditions equal to others, to be owners and to inherit assets, control their own economic matters and to have access to bank loans under equal conditions...." Therefore, it seems clear that persons with disabilities may be owners responsible for an asset and, as possessors of rights and obligations, may be obliged to compensate for the damages caused to third parties, if the circumstances or elements of the corresponding liabilities are present.

In short, the full and effective participation and integration of persons with disabilities within the civil, political, economic, social and cultural spheres make these persons (like others, and perhaps even in greater measure) potential generators of risks and damages for which they must be accountable. Were this not the case, their social integration or inclusion would not be full, in that other citizens would have serious reservations about maintaining relations in any of the aforementioned areas with persons whom the law does not oblige to take responsibility for their actions and their property.

Geneviève Viney, a distinguished French specialist in Civil Liability Law, pointed out in 1982, "on relève une répugnance très générale des droits modernes à l'égard de l'affirmation du caractère fautif de l'acte, même aberrant, commis par un inconscient (...) Mais, d'un autre côté, la plupart de ces droits s'efforcent d'assurer une réparation, au moins partielle, à la victime de tels actes en s'appuyant sur des considérations d'équité." ${ }^{1}$ With this, the author highlighted the tendency of legal regulations to equally condemn the disabled, who were not considered guilty of their damaging actions. Let us examine the present state of the issue in some contemporary civil regulatory systems and analyze if the notions of psychological disability and negligence are reconcilable.

\section{2. "Objective negligence" of the disabled person in the French Civil Code}

Article 1382 of the French Civil Code establishes that "[t]out fait quelconque de l'homme, qui cause à autrui un dommage, oblige celui par la faute duquel il est arrivé à le réparer". This is a liability based on negligence, which does not impede the French lawmaker from recognizing - in another precept - the liability of the psychologically and mentally disabled for damages caused to third parties. The full civil liability of these subjects is established in law by Article 489-2 of the Code Civile, drafted in the Act of 3 January 1968 (Law No. 68-5)². According to the precept: "Celui

\footnotetext{
1 See Viney 1982: 695.

2 The Napoleonic Code remained silent regarding this aspect, a silence that contrasted with the meticulous regulation of legal acts carried out by disabled persons. However, before the cited reform of 1968 , the Strauss Project of 30 June 1938 for the reform of psychiatric legislation established the civil liability of the mentally disabled. The text drafted for Article 54, which was not approved in the end, declared the following: "Les alienés encourent la responsabilité civile édictée par les articles 1382 et suivants du
} 
qui cause un dommage à autrui alors qu'il était sous l'empire d'un trouble mental n'en est pas moins obligé à réparation." ${ }^{3}$

Actually, the French Code does not specifically address the civil liability of these subjects, restricting itself to establishing an obligation for redress of the damages. Although the connection between the absence of discernment and negligence may not be clear in the French legislative text, it seems the lawmaker's intention was to extend the same treatment - in the extra-contractual sense - to the aliené subject with respect to the homme sensé. Perhaps for this reason, the version definitively approved by the French Parliament omits the rule pursuant to which the judge was conceded power to moderate the quantum debeatur to which the mentally ill person would be obliged. ${ }^{4}$ Thus, the reimbursement would be practically guaranteed.

Before the legislative reform of 1968 , there were two doctrinal currents regarding the concept of civil negligence. The doctrine that understood negligence as a deviation of conduct finally triumphed in the Act of $1968 .{ }^{5}$ The Mazeaud jurists defended, under the protection of objective negligence, the full capacity of all persons deprived of discernment to incur civil negligence. ${ }^{6}$ The connection between negligence and the absence of discernment is defended in this manner, though not without controversy.

In jurisprudence prior to 1968, the lack of discernment was a cause for nonimputability, though a few exceptions existed. For example, the Sentence of 18 December 1964 by the Civil Chamber of the Court of Appeals established that mental disorder does not allow the guardian of a thing or an animal to escape the responsibility arising from damages caused by the thing or animal held under guardianship or custody (Articles $1384.1^{\circ}$ and 1385 of the Code Civile). Another exception to the principle of non-imputability for the disabled applies to cases of persons unconscious due to the effect of drugs or alcohol. ${ }^{7}$ The cited Sentence of the Court of

code civil pour les actes commis par eux en déhors de l'établissement d'internement." Within the sphere of jurisprudence prior to the reform of 1968, on 31 May 1866 the Court of Montpellier declared a subject liable who had stabbed his wife while in a state of dementia, based on the grounds that if the negligence of a subject with these characteristics is excusable from the criminal repression viewpoint, it generated an obligation for compensation with regard to civil liability.

3 The criteria adopted by the French Law of 1968 clashes with the dominant and reinforced opinion in France, contrary to the liability of disabled persons. See Pothier 1805: 81. However, according to the authors of the reform, the rule for civil liability of the mentally disabled would have a therapeutic-preventative function, since this subject would be sensitive to the possibility of considerable economic losses. See Gomaa 1971: 49.

4 The text initially proposed by the French government was the following: "Celui qui a causè un dommage à autrui alors qu'il était sous l'empire d'un trouble mental n'en est pas moins obligé à réparation. Mais les juges pourront en ayant ègard à la situation respective de la victime et de l'auteur du dommage, modérer l'índemnitè mise à sa charge. Ce pouvoir de modération n'est applicable ni à la responsabilitè du fait des préposés ou des apprentis, ni aux responsabilitès du fait des choses."

${ }^{5}$ According to this concept, the negligence was likened to an error of conduct, which is to say, to an infraction of the duty of care and attention. See Mazeaud and Chabas 1986: 460.

6 MM Henri and Léon Mazeaud 1957: 447.

7 See Viney 1982: 699. 
Appeals of 18 December 1964, in the so-called Trichard Case, considered an epileptic responsible for the damages caused when, in a moment of unconsciousness, he ran the car he was driving into a pedestrian, causing this person serious injuries. ${ }^{8}$ However, despite these jurisprudential correctives to the classic "lack of responsibility" rule for the mentally ill, judges are reluctant to recognize negligence in these subjects and base such responsibility in purely objective criteria of ownership or custody of the thing or animal that caused the damage.

After the reform carried out by the Act of 1968, some authors expressed their disagreement with the legislative criteria of obliging those who suffered mental disorders to redress damages based on the premise that a person who does not have the capacity for discernment cannot act with negligence..$^{9}$ In contrast, others praised the lawmakers' decision. ${ }^{10}$ In the jurisprudential realm, there is a tendency to treat a subject suffering from a mental disturbance as a normal subject, in such a way that Article 489-2 of the French Civil Code is considered to not create an autonomous mechanism for the redress of damages caused, but rather to subject the disabled person "au droit commun de la responsabilité civile." 11 This tendency leads to the conclusion that the disabled subject is susceptible to incurring negligence, and therefore the principle of incompatibility between the absence of discernment and negligence should be abolished. ${ }^{12}$

Recently, Act 2007-308 of 5 March 2007, "portant réforme de la protection juridique des majeurs," modifies the French Civil Code with regard to senior citizens. When this modification became law (1 January 2009), the content of Article 489-2 became the object of the new Article 414-3, with a tone practically identical to that of its predecessor: "Celui qui a causé un dommage à autrui alors qu'il était sous l'empire d'un trouble mental n'en est pas moins obligé à réparation."13

If the reform of 1968 aroused criticism, it was foreseeable that the later Act would also generate contrarian opinions. Viney criticized the responsibility attributed to these persons and proposed two alternatives to keep the victim of the damage from going unprotected: ${ }^{14}$ a legally protected system of mandatory insurance for the disabled and a guarantee fund for those born disabled and not subject to legal custody or for those who suffer from sudden loss of consciousness. ${ }^{15}$

8 Viney, ibidem.

9 The Starck case, cited by VINEY 1982: 701.

10 See Le Tourneau 1971: 2401.

11 See Viney 1982: 703.

12 Viney 1982: 704.

13 See Journal Officiel ${ }^{\circ} 56$, of 7 March 2007, pgs. 4325 and following.

14 Professor Viney criticized the French lawmakers' criteria, suggesting that they replaced one injustice with another by placing the responsibility for compensation for all damages onto the person deprived of his or her capacities. See op. cit., pg. 707.

15 This author concludes her critical observation by pointing out that "il n'y aurait alors qu'avantage (...) à revenir a la solution qui faisait de l'absence de discernement une cause de non-imputabilité en matière civile," op. cit., pg. 707. 
Of course, the feasibility of both the mandatory insurance and the creation of this guarantee fund must be considered within the current socio-economic framework. The technical aspect of the mandatory insurance would very likely meet with initial opposition by the insurance companies because damages caused by disabled persons are relatively rare. The creation of a guarantee fund by the Public Administration raises an initial problem of financing and could lend itself to fraudulent actions by those feigning unconsciousness in order to have recourse to the fund.

Among all European regulatory systems, French lawmakers are undoubtedly the most outspoken in their conviction that damages caused by persons suffering mental disorders cannot be uncompensated. ${ }^{16}$ Nevertheless, it is unclear, with respect to the French legislative text, if the absence of discernment is equivalent to negligence-that is, if the conduct of a person suffering from a mental disorder can be qualified as guilty. ${ }^{17}$

Although French law might technically have an objective notion of negligence by the disabled party to justify his or her responsibility, in reality, an ad hoc model is produced that separates or differentiates the disabled from the rest of the population. ${ }^{18}$

Thus, the full reconciliation between a disabled person's negligence and his or her damaging conduct is the great question left unresolved in a regulatory system such as the French one, which does not hesitate to impose an obligation for redress of the damages caused.

\section{Lack of civil liability for the disabled in the Italian Civil Code}

The Italian Civil Regulatory System uses three guiding principles for the treatment of damages originating from a disabled person:

1) No liability for the subject who lacks the capacity to understand and to act deliberately (natural disability): "Non risponde delle conseguenze del fatto dannoso chi non ha la capacità d' intendere o di volere al momento in cui lo ha commesso, a meno che lo stato di incapacità derivi da sua colpa" (Article 2046 Codice Civile).

16 The new Civil Code of the Netherlands (2008) also allows the person causing damages while in a state of psychological disorder or anomaly to be held responsible (Art. 165.1, of the Sixth Book).

17 From the Italian doctrine, it is said that the French jurists interpret the legislative change made in their own regulation in 1968 as invariance in the lawmakers' position with respect to the mentally ill. This would pertain to a circumstance of liability without negligence, wherein the mentally ill person continues to be considered a subject lacking natural capacity. See Patti 1988: 830.

18 This is derived from the presentation of the Act of 1968 given by the Ministry of Justice to the National Assembly. After defining the legislative change as "une petite révolution juridique," Minister Foyer points out that the proposal for such reform is that of eliminating the subjective element of the negligence and maintaining the objective. See Minister Foyer's declarations, Venchiarutti 1986: 508. 
2) Responsibility of his or her guardian: "In caso di danno cagionato da persona incapace di intendere o di volere, il risarcimento è dovuto da chi è tenuto alla sorveglianza dell' incapace, salvo che provi non aver potuto impedire il fatto" (Article 2047, first subsection).

3) Subsidiary responsibility of the disabled person when the guardian does not respond: "Nel caso in cui il danneggiato non abbia potuto ottenere il risarcimento da chi è tenuto alla sorveglianza, il giudice, in considerazione delle condizioni economiche delle parti, può condannare l' autore del danno a una equa indemnità" (Article 2047, second subsection). The disabled person responds when a guardian does not exist or is insolvent or when this provides the effective and legal proof to which the transcribed precept refers. The supposition that the guardian himself could be the subject damaged by the disabled person would also have to be added to the list of cases of the disabled person's subsidiary responsibility. ${ }^{19}$

It has been emphasized that this last rule, which establishes the disabled person's subsidiary responsibility in Italian Law, has little practical application in jurisprudence, since the equating of poverty with mental illness impedes the victim from demanding a compensatory sentence on the persons affected by these disorders. ${ }^{20}$

In Italy, as in France, an alternative solution to the personal liability of people with mental illness has been proposed, whereby the mentally ill person (or his or her guardian) must either maintain insurance or create a guarantee fund to cover any damages incurred. However, its appropriateness is disputed due to the relatively infrequent and small amounts of damage caused by mentally ill people and the difficulty finding adequate specialized insurance knowledge. ${ }^{21}$

Although it has been the subject of broad doctrinal debates, it seems the responsibility to which Article 2046 refers is a subjective responsibility, based on negligence. Therefore, a person incapable of understanding and acting intentionally would be responsible in all cases wherein compensation for the damage was not upheld upon the negligence of the originator. ${ }^{22}$

19 This was observed by Venchiarutti 1988: 517.

20 See Cendon 1988: 69.

21 This consideration by Visintini 2005: 602.

22 Vis-à-vis the De Cupis option 1979: 179, which considered Art. 2046 applicable to all circumstances wherein the wrongful act had originated from a disabled person (including cases of objective responsibility), the majority of authors declared themselves against this. See, for example, Devoto 1964: 83. Likewise, Monateri states that it is senseless to ask if the guardian of a thing was imputable or not, or if the owner of a vehicle was drunk or not at the time the accident caused by its driver took place. See Monateri 1998: 263. Only in exceptional cases could the non-imputability of the vehicle's owner be considered (in cases of objective responsibility) when, for example and as Art. 2054 of the Codice Civile establishes, it is proven that the driving of the car took place against the owner's wishes. Monateri illustrates this using a (very Italian) example, wherein the owner of a Ferrari was drugged by another person so that the former would leave his car to the latter for a night, during which the latter caused an accident. Monateri 1998: 263 note 20. 
The solution given by Italian lawmakers in 1942, the year of the current Civil Code, in Articles 2046 and 2047 (no responsibility of naturally disabled, responsibility of guardian and the disabled person's subsidiary obligation of compensation) is considered anachronistic. ${ }^{23}$ It was mainly Paolo Cendon who lodged a proposal for reform of the Civil Code on this matter (the so-called Bozza Cendon of 1986), which established the direct - and not subsidiary - responsibility of the disabled agent of the damage, in possible combination with the responsibility of the guardian. In this reform proposal, the power of the judge to moderate the amount of compensation according to the age, seriousness of the disabled person's state or the economic conditions of the parties would remain unaffected. This power of judges to moderate, effective in the Italian Civil Code, was not included in the French reform of 1968, giving rise to criticism by some Italian jurists regarding this omission. ${ }^{24}$

Hence, Article 41 of the Bozza di Proposta di Legge, drafted by a group of Italian jurists led by Professor Cendon, substituted the content of Article 2046 of the Codice Civile with the following text:

\section{“Danno cagionato dall'incapace.}

Risponde del danno anche la persona che non aveva la capacità di intendere o di volere al momento in cui lo ha cagionato.

Salvo il caso in cui l'íncapacità derivi da colpa dell'autore, il giudice può moderare l'ammmontare del risarcimento, in considerazione dell'età, della gravità dello stato di incapacità e delle condizioni economiche delle parti."

Furthermore, Article 42 of the aforementioned Bozza modified Article 2047 of the Codice Civile, establishing joint and several liability for the guardian except when he or she is proven to have not been able to impede the damaging event. ${ }^{25}$

According to the principal author of the cited reform, the results do not differ significantly from the current system. A system that maintains a general principle of non-liability but retains the judge's ability to establish an equitable compensation for

The issue, however, is not without dispute. A Sentence of the Corte di Cassazione of 29 April 1993 explains that if the disabled person, in addition to being the driver who causes the traffic accident, is the vehicle's owner, he or she may not be considered responsible for the damages under the latter title.

23 See Cendon 2002: 39. This concept, which considered the regulation of the Codice to be anachronistic, was upheld due to the leanings of modern psychiatry, which considered any form of "withholding responsibility" (social, moral or legal) to be anti-therapeutic for the subject who suffered from a mental disorder. For Cendon, "la responsabilità è un prezzo necessario da pagare per l'accettazione sociale," see Cendon 2003: 40. Likewise, Visintini 2003: 194; and Petrelli 2005: 177.

24 See Autorino Stanzione 1991: 366 or Carbone 2004: 22.

25 The full text of this proposal for reform of the Civil Code, with commentary, can be found in Cendon 1987: 650.

See http://www.personaedanno.it/files/personaedanno_news it_2690_resource_orig.doc 
the victim turns into a system dominated by the general principle of the disabled person's responsibility for understanding and willful action. This model recognizes the judge's authority to moderate equitably the amount of compensation. ${ }^{26}$

With this proposal, Cendon proved to be an advocate of the revolutionary reform of the French legislature in 1968, as opposed to other Italian jurists who stated their reservations with respect to the French option ${ }^{27}$ and who even considered the current Italian Civil Code system to be unfavorable for the disabled. ${ }^{28}$ The Italian legal landscape of the past century does not lack those who justify the exemption of liability for disabled persons and for the consequences of his or her wrongful acts, assuming there exists no minimum subjective supposition of the responsibility, which allows distinguishing between the disabled person's actions and the unconscious behavior of a non-human being or an act of nature. ${ }^{29}$

Currently in Italy, there is an awakening to the necessity of substituting the regulation of the Civil Code's Article 2046 and granting more meaning and purpose to the rule of the second section of Article 2047.30 Supporters of the Bozza Cendon believe that an adaptation of the Italian Civil Code's regulations on the reform of the capacity to act in Italy (a reform realized in the Act of 9 January 2004, in which the philosophy is that of proteggere senza interdire, or "protect without disabling," through the figure of the amministrazione di sostegno ${ }^{31}$ ) would be guaranteed.

Thus, rules such as the current Article 2046 of the Italian Civil Code are not consistent with the reality that an active member of society who suffers from a mental disability is just as likely, if not more so, to commit civil wrongs. It has been said that the rule of non-liability for disabled persons constitutes the disabling rule par excel-

26 Cendon himself describes this in what we could consider a genuine interpretation of the regulation.

27 Thus, Bianca 1985: 36, Autorino Stanzione 1991: 369, or Busnelli and Patti 2003: 348.

28 An extremely interesting point, along these lines, is the doctrinal discussion held at the beginning of the 1980's between Patti (for whom the regulation of Article 2047 was favorable for the disabled person in that it established one simple subsidiary responsibility and could be modified by the judge) and De Cupis (who, in contrast, considered such a regulation to not be covered in the catalogue of civil rules favorable to disabled persons, in that it assumed a rule of objective responsibility). For more on the chronology of this doctrinal controversy, see De Cupis 1982: 763; Patti 1983: 642; and, again, in De Cupis 1984: 253.

29 See Falzea 1960: 43.

30 See Visintini 2005: 600. According to Visintini, the rule of the second section of Article 2047 shows little practical application due to the less-than-affluent economic conditions in which the disabled often find themselves. The author calls for greater attention to this subject and the putting into practice of this precept, demanded by the new guidelines of the special legislation on psychiatric assistance aimed at a greater responsabilizzazione degli infermi di mente. Ibidem. Contrary to this, other authors, such as ZenoZencovich, show themselves to be advocates of maintaining the current system and maintain that any legislative reform of Articles 2046 and 2047 of the Codice Civile would lack practical significance because of the scarce application of both rules, due to the common insolvency of disabled persons. See Zeno-Zencovich 1986: 13.

31 See in this respect Carbone 2004: 22. 
lence, in that it excludes the damaging behavior from being evaluated pursuant to the criteria of negligence. ${ }^{32}$

In 1986, the Bozza Cendon was also the object of criticism with respect to the civil liability of disabled persons. The objections claimed that the obligation for compensation by the disabled person would protect the victim but would also further weaken the position of the disabled, whom society should protect. However, it was deemed unacceptable for disabled persons to contribute to reducing the responsibility corresponding to health care institutions. ${ }^{33}$

Another proposal for reform of the Civil Code was drafted in 2007. Its promoter was again Cendon. This proposal was titled "Rafforzamento dell'amministrazione di sostegno e abrogazione dell'interdizione e dell'inabilitazione." The content of the current Articles 2046 and 2047 of the Civil Code is replaced by Articles 73 and 74 , in terms that are consistent with the previous Bozza of 1986. Specifically, they establish the direct responsibility of the disabled person (which the judge may temper depending on the circumstances) and joint and several liability for the guardian. ${ }^{34}$

This new proposal for reform is justified by the dominant trend in Europe to encourage the autonomy of disabled persons, eliminating those vestiges of differentiated treatment such as prohibition or incapacitation ("interdizione" or "inabilitazione") or the exemption of civil liability for wrongs committed.

\section{Other European civil regulatory systems: Portugal, Germany and Switzerland}

Portugal's treatment of this issue in its Civil Code is practically identical to that of the Italian Code. Article 488, entitled "Imputabilidade," like 2046 of the Italian Code sets forth the following: "1. Não responde pelas consequências do facto danoso quem, no momento em que o facto ocorreu, estava, por qualquer causa, incapacitado de entender ou querer, salvo se o agente se colocou culposamente nesse estado, sendo este transitório." Nonetheless, the Portuguese legislature establishes, in the second rule of this precept, a presumed lack of imputability with respect to persons who are disabled due to mental disorder. Although this presumption may be iuris tantum, it can make things more difficult for the victim of damages incurred by a person who unexpectedly preserves his or her ability to discern.

32 See. Morozzo Della Rocca 1998: 676.

33 See such critiques in Comporti 2002: 93. These critiques culminate in the authors recommending the creation of a fighting fund that would allow for compensation of the most serious personal damages caused by disabled persons.

34 This legislative proposal, cited previously, may be read at http://www.personaedanno.it/files/personaedanno news it 2690 resource orig.doc 
The responsibility in these cases would be transferred to the persons obliged to guard or watch over the disabled person (Article 491), just as established in the first paragraph of the Italian Code's Article 2047.

In a manner practically identical to the second paragraph of Article 2047, 489 regulates subsidiary compensation, based in equity, at the cost of the disabled person. This precept declares the following: "1. Se o acto causador dos danos tiver sido praticado por pessoa não imputável, pode esta, por motivo de equidade, ser condenada a repará-los, total ou parcialmente, desde que não seja possível obter a devida reparação das pessoas a quem incumbe a sua vigilância. 2. A indemnização será, todavia, calculada por forma a não privar a pessoa não imputável dos alimentos necessários, conforme o seu estado e condição, nem dos meios indispensáveis para cumprir os seus deveres legais de alimentos."

We must nevertheless observe that Portuguese lawmakers, unlike their Italian counterparts, disregard the economic conditions of the other "party" as an extracontractual obligation. The victim's financial condition is not considered relevant, but the consistency and solvency of the obliged person's assets is deemed relevant.

In Germany, the general rule is that of exoneration of responsibility for those who cause damage to another while in a state of unconsciousness or with an altered intellectual activity that precludes the free determination of will (paragraph 827 of the "BGB," or German Civil Code). ${ }^{35}$

The general rule for exoneration of responsibility has a counterpart, established in paragraph 829, which establishes the disabled person's duty to compensate for reasons of fairness. The cited paragraph establishes, "Those in the circumstances described in paragraphs 823 to 826 are not responsible for damages caused by them, pursuant to paragraphs 827 and 828, but they must in any case repair the damage caused, provided the compensation for the damages cannot be claimed against a third party obliged by a duty of control and if, in accordance with the circumstances, and especially the relations between the participants, a compensation in keeping with equity is enforceable and this does not deprive these subjects of the resources they need to attend to their adequate sustenance or those for fulfillment of their legal obligation to provide food to their disabled charge."

The equitable compensation set forth by Germanic Law has some similarities with that established in Italian Law (Article 2047 of the Codice Civile). It is subsidiary with respect to the compensation enforceable on the guardian or person with duty of con-

35 In former German Law, persons who suffered mental disorders were exempt from criminal liability but not from civil compensation for the damages. In this way, the Prussian Landrecht of 1794 established the compensation of the damage caused by the insane, provided it was not possible to obtain such compensation from the subjects entrusted with his or her custody (Law 6, paragraph 41). See this reference in Comporti 2002: 54. 
trol over the material originator of the damage, and it depends on certain circumstances, such as relations between the agent of the damage and the victim (elements which do not appear in the Italian Code's 2047.2) or the economic conditions of the disabled person. Just as in Portuguese Law, the economic situation of the victim is not expressly addressed. ${ }^{36}$

Similar to the Italian, Portuguese and German regulations on this matter are the Swiss (Article 54 of the Code of Obligations) and the Belgian (Article 1386 bis of the Civil Code) ${ }^{37}$ regulations. Nevertheless, in both systems, equitable compensation required from the disabled person is not expressly subsidiary in the absence of liability for the persons entrusted with care of the disabled person.

Article 54 of the Code of Obligations of 1911 establishes the following: "B. Responsabilité des personnes incapables de discernement

${ }^{1}$ Si l'équité l'exige, le juge peut condamner une personne même incapable de discernement à la réparation totale ou partielle du dommage qu'elle a causé.

${ }^{2}$ Celui qui a été frappé d'une incapacité passagère de discernement est tenu de réparer le dommage qu'il a causé dans cet état, s'il ne prouve qu'il y a été mis sans sa faute."

There is currently a Swiss Federal Bill for the Revision and Unification of Civil Liability Law, drafted by Widmer and Wessner. This Bill gives a new wording to the regulatory precept for disabled persons. Article $48 \mathrm{~b}$ ) of the new pre-regulatory text states the following: "En cas d'incapacité de discernement.

Si l'équité l'exige, eu régard notamment à la situation économique des parties, le tribunal peut exceptionnellement condamner une persone incapable de discernement à la réparation partielle ou totale du dommage qu'elle a causé."

${ }^{36}$ Outside of Europe, Japan used the "Bürgerliches Gesetzbuch" as its model in order to draft many of the regulatory precepts of its Civil Code. In this specific aspect, it exonerates those without the capacity for the discernment necessary to understand the scope of their actions (Article 713 of the Nippon Code). There is a difference in nuance between this phrase of the Japanese Code and the corresponding one of Article 827 of the BGB, which refers to the state of unconsciousness or an illness that affects the free determination of will and not the capacity to understand the results of the action. In this sense, I think the Japanese expression is the more suitable, because what is important is not so much the alteration of will but the alteration of the capacity for discernment.

On the other hand, the Japanese Code does not establish a rule for subsidiary compensation by the disabled person based in equity, as the BGB does.

37 Article 1386 bis states the following: "Lorsqu'une personne se trouvant en état de démence, ou dans un état grave de déséquilibre mental ou de débilité mentale la rendant incapable du contrôle de ses actions, cause un dommage à autrui, le juge peut la condamner à tout ou partie de la réparation à laquelle elle serait astreinte si elle avait le contrôle de ses actes.

Le juge statue selon l'équité, tenant compte des circonstances et de la situation des parties." 
Aside from eliminating the actio libera in causa contained in the second rule of Article 54 of the Code of Obligations, the Bill on Civil Liability expressly sets the economic situation of the parties as the principle criteria for equity, an expression identical to the Belgian Civil Code and similar to those of the other systems that regulate this equitable compensation. The Swiss doctrine and jurisprudence place this norm within the framework of objective responsibility, while acknowledging that this concerns an atypical rule that turns it more into an exception than into a true rule of objective responsibility. ${ }^{38}$

Disability and negligence are, in most European regulatory systems, considered incompatible ideas.

\section{Latin American civil regulatory systems}

A considerable number of the Civil Codes in Latin America, including Peru, Venezuela and Brazil, follow the rule of exonerating the disabled person of liability, but grant the judge the option to set an equitable and subsidiary compensation in circumstances where the victim cannot obtain redress from the person legally entrusted with watching over or caring for the disabled person. This follows the criteria of many European regulatory systems, such as the Italian, Portuguese and German systems.

Book VI of the Peruvian Civil Code, entitled "Fuentes de las obligaciones" (Sources of Obligations), has three precepts directed at regulating the responsibility of disabled persons. Article 1975, "Responsabilidad de incapaces con discernimiento" (Responsibility of the Disabled with Discernment), establishes the following: "The person subject to disability of exercise is obliged for redress of the damages he or she may cause, provided this person has acted with discernment. The disabled person's legal representative is jointly and severally liable." In addition, Article 1976, "Responsabilidad de representantes de incapaces sin discernimiento" (Responsibility of Representatives of Disabled Persons without Discernment), states, "There is no liability for the damage caused by a disabled person who has acted without discernment, in which case his or her representative will be held responsible." Similar to the aforementioned European Laws, Article 1977 of the Peruvian Code establishes equitable compensation, stipulating, "If the victim has not been able to obtain redress or compensation in the previous circumstance, the judge may, in view of the parties' economic situation, consider an equitable compensation ordered on the direct originator. ${ }^{139}$

38 See Widmer and Wessner, "Revisión et unification du droit de la résponsabilité civile. Rapport explicatif", pgs. 121 and following. See http://www.ejpd.admin.ch/etc/medialib/data/wirtschaft/gesetzgebung/ haftpflich.Par.0003.File.tmp/vn-ber-f.pdf. See also Werro 1986: 126.

39 Leysser L. León points out that with regard to Article 1977 of the Peruvian Code, there were in operation "two common places, to wit, which would mean a circumstance of 'objective civil liability,' and that the criteria for imputation given expression there is that of 'equity.'" The author shows himself to be in disagreement with both considerations. 
As evidenced by the tone of these precepts, what is most significant about the Peruvian text is that it links the disabled person's responsibility with his or her capacity for discernment and holds the legal representative responsible in the event such capacity does not exist. The question of who is responsible if a de facto guardian exists (instead of a legal representative) would need to be resolved.

It is important to highlight the sensible distinction between the capacity for discernment and the incapacity for discernment. This idea is not predominant in European Codes. The Venezuelan regulation is practically identical to the Peruvian one (Articles 1186, 1187 of the Venezuela Civil Code), with the notable difference that the Venezuelan Code does not establish the joint and several liability of the disabled person's "legal representative," considering this to be a liability that (as I also say) could be unnecessary.

An equitable compensation established in a subsidiary manner seems to be the common denominator for most Civil Laws in Latin America. In Brazil, as in Peru or Venezuela, this is the object of regulation in the second paragraph of Article 928 of the Civil Code. Unlike the others, however, disabled persons are not differentiated according to those with the capacity for discernment and those without.

The criteria adopted in the Federal Code of Mexico are somewhat different. In the Mexican text, the disabled person's responsibility (not equitable compensation) is subsidiary to the responsibility of his or her legal representative (Article 1911 in relation to 1921 and 1922). The disabled person is also not differentiated between having the capacity for discernment and not having such capacity. His or her responsibility, always subsidiary, is independent from his or her capacity for discernment. Moreover, it does not seem to be based upon equity but upon objective responsibility.

In Latin American civil regulatory systems, there are countries, like Ecuador, whose code completely exonerates the "demente" (insane) of responsibility (Article 2246 of the Civil Code). Costa Rica omits any express reference to this matter and moves it to the criminal regulatory system through its Article 104, the tone of which is reminiscent of the Spanish Criminal Code's Article 118.1.1': "In cases of non-imputability [understanding this as criminal], the disabled person's liability subsists, provided his or her food or hospitalization expenses remain guaranteed, and out of this liability, his or her parents, guardians, custodians or entrusted parties who could have avoided the damage or oversight in their care duties will be responsible in a subsidiary manner. The same rule will be applied in the case of those partially imputable."

Finally, it is worth noting the so-called evolution that Argentina is attempting to implement on the matter. The current rule allows no responsibility for the "demente" (Article 1076 of the Civil Code).$^{40}$ The rule is considered unjust in some cases where

${ }^{40}$ A rule reinforced by that established in Article 921 of the same legal text: “The acts will be considered events without discernment if they were legal acts exercised by prepubescent minors, or wrongful 
a disabled person with high purchasing power causes damage to a person with few resources upon which his or her entire family depends. In those situations, the victim must rely upon causes of action like unjust enrichment or the theory of risk caused by things in one's service or care. ${ }^{41}$

A radical change in this subject arose from the Civil Code Project of 1998 for Unification of Private Law in Argentina, which established in its Article 1618 that in involuntary acts, the responsible party is "...he or she who acts without discernment, without effect upon the responsibility of the legal representative who may correspond, as the case may be." This new standard is equivalent to the French rules in terms of the responsibility of disabled persons.

\section{The "objective negligence" of the disabled in the Common Law System}

The North American experience is relevant to understanding the idea of objective negligence in a common law system. There are two principles that guide the treatment of the mentally ill hospitalized at specific health centers. On the one hand, the purpose of the treatment must be the sick person's recovery and his or her integration into the community. On the other hand, treatment of the mentally ill must be carried out pursuant to methods that encourage the patient's freedom and favor his or her "assumption of responsibility." In the United States, the general rule is that of responsibility assigned to persons who suffer mental disorders for damages caused to third parties. ${ }^{42}$ The 1948 updating of the Restatement of Torts sets out the principle of the disabled person's responsibility (paragraph 283), and the Restatement (Second) of Torts of 1965 confirms this principle (paragraph 283 B). ${ }^{43}$ Some states incorporated this rule into their regulatory systems, such as California (Civil Code, Section 41) or Montana (Code Annotated, Section 27-1-711), wherein liability for damages is established (with the exclusion of "exemplary damages," unless the person has the capacity to understand the scope of these). ${ }^{44}$ However, others (such as Louisiana) fol-

\footnotetext{
acts by minors less than ten years old; as well as also acts of the insane which were not carried out during lucid intervals, and those carried out by those who, due to any accident, are without the use of reason."

41 See Seuba Torreblanca, Farnós Amorós and Fernández Crende 2004: 12.

42 In the scope of North American Common Law, the leading case on this matter is considered Williams versus Hays (1899). The Ruling and commentary thereon can be seen in Hornblower 1905: 278. Actually, the case does not refer to a person suffering a mental disorder, but to the captain of a ship who, after steering it for over forty-eight hours, ingests a medicine with quinine and falls into a state of unconsciousness. Not long afterward, the ship wrecks. Although the captain is exempted of responsibility, the judges declare, "the general rule is that an insane person is just as responsible for his torts as a sane person." Based upon this, the principle of responsibility for the disabled person becomes a "rule of law" in Anglo-American Law.

43 However, this has not always been the predominant rule. In the first Restatement of Torts (published in 1934), Paragraph 283 established that "a reasonable person standard should be employed unless the actor is an insane person."

44 See Splane 1983: 153.
} 
low the rule of Civil Law, which views the mental illness as a cause for exoneration of responsibility. ${ }^{45}$

As in France, the standard for enforceable negligence is an objective standard that ignores the specific mental competences of the subject. In the United States, however, social reasons prevail over legal ones when considering the responsibility of a person suffering from a mental disorder. It is said that the adoption of exemption of responsibility would produce a reaction from the entire community against attempts to integrate these persons into mainstream society. The community would theoretically avoid any contact or legal relations with them due to their lack of responsibility, and the social consciousness would provoke the need to return to a structure of imprisonment and isolation for the mentally ill. ${ }^{46}$ In short, anything that emphasizes these subjects' different qualities may contribute to increasing their social isolation.

In American Law, debate has also arisen regarding the accusation of negligence for disabled persons in wrongful acts whereby the disabled person himself is damaged. In these cases, unlike others in which the disabled person is the originator of the damage, a criterion of subjective negligence is used. Thus, if the disability is absolute, negligence is not observed, nor is any consequent reduction in the compensatory quantum. Should this not be the case, a determination of negligence may be considered. The mentally ill person who is a victim of damage in which he or she has collaborated appears, according to this view, a less threatening and dangerous subject than the disabled originator of the damage. This distinction has been the subject of strong criticism among some American authors. ${ }^{47}$

In my opinion, the adoption of objective criteria of negligence for one case and subjective criteria for another lacks grounding. It would mean treating the same conduct differently depending upon the victim, an unjustified distinction. It is also important to consider the idea of objective negligence, profiled pursuant to the mold of the "reasonable man," as the suitable criteria - as has been said ${ }^{48}$ - with the goal of integrating disabled persons into society. As I have argued previously, the objective criteria is "penalizing" not only with respect to disabled persons, but also with respect to any person who, due to any circumstance, cannot have the diligence inherent in the indefinable "average man" or reasonable man enforced upon him.

\section{Recapitulation and conclusions: The Principles of European Tort Law and adaptation of the conduct standards}

The different systems discussed can be combined into two large groups:

\footnotetext{
45 See Splane 1983: 156.

46 See these ideas in Comporti 2002: 84, and in Zeno-Zencovich 1988: 850.

47 See Splane 1983: 157.

48 Splane 1983: 160.
} 
a) Those regulatory systems that begin from a presumption of non-responsibility for the disabled person. In order to not leave the victim completely unprotected, they establish the possibility of a subsidiary compensation founded exclusively on equity. This is based on the presumption that the disabled person cannot be held personally accountable for his or her actions. The foundation of this responsibility is equity, or even objective responsibility or risk liability.

b) All others that establish the full civil liability of the disabled person, albeit due to or based on a concept of ad hoc negligence, different from and stripped of any subjective nuances (France or Common Law regulatory systems).

It is not easy to determine where the Spanish regulatory system is positioned. The Civil Code's silence in this respect and the particular regulation of the Criminal Code do not allow a clear observation as to whether the possible civil liability of the disabled person is grounded in a responsibility due to objective negligence, which would closely approximate objective responsibility, or is framed within the same concept of negligence applicable to anyone else, albeit with the subjective variations of standards of conduct.

In my opinion, the standard of conduct applicable to persons with disabilities can be adapted to the mental characteristics of the group of people to which the person committing the damage belongs, pursuant to certain norms or parameters. ${ }^{49}$ The Principles of European Tort Law (PETL) ${ }^{50}$ seem to operate along these lines (Article $4: 102) .{ }^{51}$ The evolution of this matter is considerable: from exonerating these persons of responsibility for their inability to adhere and adapt to an average standard of conduct, to an adapted standard of conduct made more flexible in relation to persons' circumstances so that they can be considered guilty and, consequently, susceptible to liability for damages incurred by third parties.

\section{REFERENCES}

Autorino Stanzione, G. 1991. “Sulla responsabilità dell'infermo di mente nell'esperienza francese". Rassegna di Diritto Civile 1: 366.

49 See Yáñez Vivero 2009: 59.

50 The Principles of European Tort Law were drafted by the European Group on Tort Law and presented in Vienna in May 2005. See the multiple works of one of the authors of these Principles, Martín-Casals 2005: 12; or Martín-Casals 2002: 16.

51 Art. 4:102. Required standard of conduct

(1) The required standard of conduct is that of the reasonable person in the circumstances and depends, in particular, on the nature and value of the protected interest involved, the dangerousness of the activity, the expertise to be expected of a person carrying it on, the foreseeability of the damage, the relationship of proximity or special reliance between those involved, and the availability and the costs of precautionary or alternative methods.

(2) The above standard may be adjusted when due to age, mental or physical disability or due to such extraordinary circumstances that the person cannot be expected to conform to it. 
Bianca, M. 1985. "La protezione giuridica del sofferente psichico". Rivista Diritto Civile 1: 36.

Busnelli, M, and Patti, S. 2003. "Danno e responsabilità civile". P.348 in Responsabilità civile. Studi di diritto privato. Turin: Giappichelli Editore.

Carbone, A. 2004. "Libertà e protezione nella reforma dell'incapacità d'agire" in http://www.altalex.com/index (June 3th 2010).

Cendon, P. 1987. "Infermi di mente e altri disabili in una proposta di riforma del diritto civile". Politica del diritto: 650.

Cendon, P. 1988. "Profili dell'infermo di mente nel diritto privato." P. 69 in Un altro diritto per il malato di mente. Naples: Edizioni Scientifiche Italiane.

Cendon, P. 2002. "La tutela civilistica dell'infermo di mente." Pp. 39-40 in La riforma dell'interdizione e dell'inabilitazione. Milan: Quaderni di familia.

Comporti, M. 2002. "Commentario al articolo 2046 Codice Civile." Pp. 92-93 in Commentario al Codice Civile. Milan: Giuffrè.

De Cupis, 1979. I/ danno. Teoria generale della responsabilità civile. Milan: Ed. Giuffrè.

De Cupis, 1982. "Il favor del diritto civile per gli incapaci", Rivista di Diritto Civile 2: 763-764.

De Cupis, 1984. "Postilla sul favor del diritto civile per gli incapaci, Rivista di Diritto Civile 2: 253-254.

Devoto, L. 1964. L'imputabilità e le sue forme nel diritto civile. Milan: Ed. Giuffrè.

Gomaa, 1971. "La réparation du préjudice causé par les malades mentaux." Revue Trimestrielle de Droit Civile: 49.

Hornblower, 1905. "Insanity and the Law of Negligence". Columbia Law Review 5: 278-279.

Le Tourneau, 1971. "La responsabilité civile des persones atteintes d'un trouble mental". Juris-Classeur Periodique 1: 2401.

Patti, S. 1983. "Ancora sul favor del diritto civile per gli incapaci (e su una innovazione, di segno opposto dell'ordinamento francese". Rivista Diritto Civile 2: 642.

Petrelli, P. 2005. "Questioni aperte in tema di responsabilità civile", P. 177 in Amministrazione di sostegno, compiled by Ferrando. Milan: Ed. Giuffrè.

Martín-Casals, M. 2002. "Reflexiones sobre la elaboración de unos principios europeos de responsabilidad civil, 2nd Conference of the spanish association of lawyers specialized in civil liability and insurance, at http://www.asociacionabogadosrcs.org/ponencias/pon2-7.pdf

Martín-Casals, M. 2005. “Una primera aproximación a los Principios de Derecho europeo de la responsabilidad civil." Revista Indret 2: 12.

Mazeaud, 1957. Traité theorique et pratique de la responsabilité civile délictuelle et contractuelle. Revised by Tunc. Paris: Éditions Montchrestien.

Mazeaud and Chabas, 1986. Leçons de droit civil: obligations, théorie générale. Paris: Éditions Montchrestien.

Monateri, 1998. "La responsabilità civile." P. 263. Trattato di diritto civile compiled by Sacco. Turin: Ed. Utet.

Morozzo Della Rocca, "L'imputabilità ". P. 676 in La responsabilità civile. I/ diritto privato nella giurisprudenza compiled by Cendon. Turin: Ed. Utet.

Patti, 1983. "Ancora sul favor del diritto civile per gli incapaci (e su una innovazione, di segno opposto dell'ordinamento francese". Rivista Diritto Civile 2: 644.

Bregoli, 1988, "Figure di sorveglianti dell'incapace dopo l'avvento della legge 1802," P. 830 in Un altro diritto per il malato di mente. Esperienze e soggetti della trasformazione, compiled by Cendon. Naples: Edizioni Scientifiche Italiane. 
Seuba Torreblanca, Farnós Amorós and Fernández Crende, 2004. “Daños causados por personas con trastornos mentales". Indret 2: 12-15 (www.indret.com).

Splane, 1983. "Tort liability of the mentally ill in negligence actions". Yale Law Journal 93: 153.

Venchiarutti, 1986. "La responsabilitá civile degli inferni di mente in Francia". Rivista Critica di Diritto Privato 1: 508.

Venchiarutti, A., 1988. "La responsabilità civile dell'incapace," P. 517 in La responsabilità civile. Saggi critici e rassegne di giurisprudenza, compiled by Cendon. Milan: Ed. Giuffrè.

Viney, G., 1982. Les obligations. La responsabilitè: conditions. Paris: Librairie Générale de Droit et de Jurisprudence.

Visintini, G., 2005. Trattato breve della responsabilità civile. Padova: Cedam.

Visintini, G., 2003. "La crisi dell' nozione di imputabilità nel diritto civile." P. 194 in Follia e diritto. Bollati Boringhieri Editore

Werro, 1986. La capacité de discernement et la faute dans le droit suisse de la responsabilité. Fribourg: Editions Universitaires Fribourg Suisse

Yáñez, F. 2009. Culpa civil y daño extracontractual originado por persona incapaz. Pamplona: Thomson-Aranzadi.

Zeno-Zencovich, 1986. "La colpa oggettiva del malato di mente: le esperienze nord-americana e francese". Responsabilitá civile e previdenza 1, 13.

Zeno-Zencovich, 1988. "La colpa oggettiva del malato di mente: esperienze nord-americana e francese."P. 850 in Un altro diritto per il malato di mente. Esperienze e soggetti della trasformazione, compiled by Cendon. Naples: Edizioni Scientifiche Italiane. 


\section{ARTICULOSSARTIILLES}

The 2006 New York Convention and Obligations of Persons with Disabilities: Liability for Damages within the Scope of Civil Law and Common Law / Las obligaciones de las personas con discapacidad psíquica a la luz de la Convención de Naciones Unidas de 2006: especial consideración de la responsabilidad por daños

Fátima Yáñez Vivero

Concepto y problemática social del sectarismo: reflexiones para el trabajo social a partir de modelos históricos / Concept and Social Issues around Sectarianism: Considerations for Social Work based on Historical Models

David Hernández de la Fuente

Págs 29-42

Conflicto ético, diálogo e intervención social: la propuesta de "diálogos morales" de Amitai Etzioni / Ethical conflict, dialogue and social action: the proposed "moral dialogues" of Amitai Etzioni José Antonio Ruiz San Román y Leticia Porto Pedrosa

Trabajo Social y jóvenes: el descubrimiento de los otros a través del voluntariado social / Social work and youth: the discovery of others through volunteering social

Miguel del Fresno García y Sagrario Segado Sánchez-Cabezudo

Págs 55-70

Evaluación de la cognición, la conducta y la funcionalidad de las personas mayores dependientes en los centros residenciales / Assessment of cognition, behaviour and functionality of dependent elderly people in residential centers

María del Carmen Díaz Mardomingo

Págs 71-91

\section{RESEĨAS/REVIIEWS}

Miguel del Fresno. Netnografía / Miguel del Fresno. Netnografy (por Jairo Alonso Rozo)

David Hernández de la Fuente. Vidas de Pitágoras según Porfirio, Jámblico, Diógenes Laercio,

Diodoro de Sicilia, Focio di Costantinopla / The lives of Pythagoras according to Porphyry, lamblichus, Diogenes Laertius, Diodorus of Sicily and Photius of Constantinople (por Federica Pezzoli)

Antonio Gutiérrez Resa y Octavio Uña Juárez. Integración de los inmigrantes a través de los servicios sociales municipales en la Comunidad de Madrid / Integration of immigrants through local public social services in the region of Madrid (por Francisco Javier García Castilla)

Antonio López Peláez. Teoría del Trabajo Social con grupos / Theory of social work with groups (por José Ángel Martínez López)

María Crespo Garrido, Fernanda Moretón Sanz. Conciliación de trabajo y familia. Las claves del éxito: eficiencia empresarial e implicación masculina / Reconciling work and family. Keys to success: business efficiency and male involvement (por Inmaculada Vivas Tesón) ...... 